\title{
PACIFYING THE ‘ARMIES OF OFFSHORE LABOUR’ IN CANADA
}

\author{
ADRIAN A. SMITH \\ Department of Law \& Legal Studies, Institute of Political Economy, \\ Institute of African Studies, Carleton University ${ }^{1}$
}

\begin{abstract}
An exploration of the link between pacification and global apartheid in the context of the racialized effects of neoliberal labour migration is undertaken. Drawing on the general layout of Canada's temporary labour migration regime, the legal regulation of migrant labour is taken as a project of pacification that enforces apartheid conditions. Juxtaposed against the construction of migrant labour as menace or threat to 'host' communities in Canada, the growing need for "armies of offshore labour" presents an especially acute challenge for capital and national states. Despite certain perceptions that it is freed from national state constraints owing to the hyper-competitiveness of contemporary migration, capital remains deeply beholden to the politico-legal interventions of states, both sending and receiving. Situated within the hierarchical and uneven logic of the nation-state system and global capitalist development, pacification becomes a way in which capital and states attempt to mediate contradictions and govern not "insecurities" surrounding human mobility but rather the need to fabricate productive labour, a need contingent upon the complex transnational legal regulatory dynamic of unfree migrant labour which itself relies upon and perpetuates apartheid.
\end{abstract}

\section{Keywords}

unfree migrant labour, pacification, global apartheid, racialization, anti-security.

\section{Introduction}

A recent dispute over the relocation of migrant worker housing makes evident the contradictory reasoning of contemporary labour migration. In a lament for small-scale

\footnotetext{
${ }^{1}$ Based in Canada, Adrian A. Smith is a scholar and image-maker who teaches in Carleton University's Department of Law and Legal Studies and Institute of Political Economy. He is a member of Justice For Migrant Workers and serves in several editorial positions, including as book reviewer editor of Socialist Studies. Contact: adrian.smith@carleton.ca. Adrian wishes to gratefully acknowledge and thank the two anonymous reviewers, as well as Elaine Coburn, Mark Neocleous, George Rigakos and Dayna Scott -- all of whom provided constructive feedback on this project.
} 
industrial agriculture in southwestern Ontario, a community resident remarking on the "alarming rate" of acquisition and consolidation of small farm holdings by large ones noted "the need for armies of offshore labour ... to run these huge operations". ${ }^{2}$ This particular framing, wrapped up as it is with an explicit 'NIMBYism', runs head-on into the securitized discourse in which contemporary migration practices are shrouded. The expressed concern, which encapsulates sentiments held more widely, posits at once the necessity of migrant labour in contemporary agricultural production and the threat posed by invading outside forces on pristine and unsuspecting local communities. This "outsider threat" - and the othering processes on which it is formulated - turns on the perception of imminent danger wrought by migrant farm hands (or, perhaps more aptly, at the hands of migrant labour), the same hands which also are portrayed as necessary to rural economic development.

The premise of this article is that the construction of migrant labour in security terms is deeply flawed. Rather than migrant workers rendering local communities "insecure", the legal regulation of labour migration engages in a project of pacification with dire implications for migrant labouring bodies. Ultimately, through the articulation of an anti-imperialist, anti-security analytical account, I aim to show that the pacification of neoliberal migration masks the skewed calculus by which the migration of temporary labour to Canada occurs. That calculus, contingent on the faulty logics of the hierarchical nation-state system and uneven capital accumulation, results from and in "racialized structural inequality" (Galabuzi 2006) on a global scale or, more succinctly, global economic apartheid. ${ }^{3}$

An introductory section sketches the contours of an anti-security account grounded in pacification. Next, the discussion situates neoliberal migration within the context of a global apartheid. In the final section I mount an anti-security analysis illustrating how Canada's temporary labour migration regime serves as a form of pacification in which labouring bodies are rendered productive in racialized, unfree and migrant forms. This offers a necessarily general account of Canada's migration regime as it relates to pacification and apartheid, instead of opting to focus on narrow and limited conceptions of the legal regulation of labour migration. Existing understandings of the role of law in migration tend to operate within analytical frameworks artificially

\footnotetext{
${ }^{2}$ Elsewhere, I have examined written objections of Norfolk County community residents to the migrant housing proposal with a view to understanding how their consciousness about law informs actions of exclusion undertaken by these same residents and by the state. See Smith 2013.

${ }^{3}$ Racialized groups in Canada are disproportionately relegated to precarious employment (Galabuzi 2006. See also Vosko 2005) based on "a logic similar to that of the apartheid regime in South Africa" (Galabuzi 2006, xiv). For Grace-Edward Galabuzi, economic apartheid marks the segmentation of labour markets through racialized segregation and exploitation the result of "the persistent structures of racialized undervaluing of human capital, racialized under compensation for labour, and racialized income inequalities to benefit capital accumulation" (Galabuzi 2006, 249).
} 
truncated and constrained by disciplinary distinctions. Take, for instance, prevailing approaches to the study of labour and employment law. These approaches develop (and remain) within discrete sub-disciplines which cannot alone capture the full complexities of legal regulatory controls imposed to channel migratory flows. Bounded disciplinary inquiry curtails appreciation of the imposition of myriad controls on migrant labour. The analytical approach is reflected in practice where certain left labour lawyering agendas address the imposition of controls on migrant labour in discrete and insular silos (see e.g. Ontario (Attorney General) v. Fraser). This was evident in the arguments of unions and worker associations in the Fraser case at the Supreme Court of Canada, concerned with the freedom of association rights of agricultural workers in Ontario, where the post-war industrial unionism model of labour relations was promoted as an appropriate basis on which to organize migrant labour without meaningful recognition of the impediments posed through other areas of law, especially immigration law.

There is a need for a new conception of the migrant labour and legal regulatory relationship, one that transcends prevailing disciplinary orthodoxies, including within the fields of labour law and immigration law. Taking as a point of departure the pacification of labour, the challenge is to unmoor conceptions of legal regulation of labour from strict association with collective bargaining and employment standards alone. This unmooring would allow for more systematic analytical engagement with immigration, criminal, business and other legal regulatory regimes which, whether possessed with official authority over labour or not, serve to discipline and regulate 'it'. That said, although the ongoing centrality of law proves crucial, it is not law alone which shapes and disciplines peoples' everyday lives. We must also, therefore, engage with how other social processes - most notably, racialization - interact with legal regulatory phenomena to produce and reproduce migrant labour.

\section{Pacification and Neoliberal Migration}

Under neoliberal capitalism, we have seen a deepening of efforts to have immigration policies work in service of the accumulation of capital. Yet, few legal theorists have paid attention to capital accumulation and its material impacts on workers. Instead, critical approaches to the role of law within neoliberal migration focus on national security (Macklin 2001; Aiken 2001; Dauvergne 2007). Narrow and insular, the bourgeois conception of national security resting at the heart of immigration enforcement instruments and policies produces what Audrey Macklin calls "the immigrant-as-security-threat leitmotif" (Macklin 2001, 384). This accords with the characterization of new immigrants as "dangerous foreigners", evident in early twentiethcentury Canada, as Donald Avery's (1983) classic study attests. Although far from new, early twenty-first century attempts to couple anti-terrorism measures with immigration 
regulation has "institutionalized in law the figure of the immigrant as archetypal menace to the cultural, social, and political vitality of the nation" (Macklin 2001, 392. See also Dauvergne 2007; 2009). This has resulted in an erosion of citizenship rights for specified targets of the post-9/11 agenda, especially those perceived as Arab or Muslim, ${ }^{4}$ as Canada's anti-terrorism measures were designed "to alienate the subject from social citizenship, even if legal citizenship is already secured” (Macklin 2001, 398).

With respect to racialization, national security has been subjected to critique in critical discussions of the phenomenon of racial profiling (Bahdi 2001; Choudhry 2001). The reliance on "race as a proxy for risk" or as a "substitute for real knowledge about an individual's connection to, or propensity for, terrorist activity" (Bahdi 2001, 295), is said to produce insecurity for those subjected to this form of objectification. Yet the charge of racial profiling does not aptly register the full depth of disagreement. In one sense, the prevailing take on racial profiling draws attention to a set of practices constructed as alien or exceptional, even when perceived as troubling. In discounting systemic and historical challenge, these accounts fail to capture "a racialized culture of hegemonic whiteness" and economic apartheid as endemic within migration policies as well as within the wider formation of the Canadian state and associated nation building project (Bakan 2008; Gordon 2007; Banaji 2000; Thobani 2007). In another sense, these interventions resort to the same deeply problematic logic of security. In particular, invocations of 'risk' and 'insecurity' and of 'security' as a common good reproduce rather than question and interrogate the neoliberal security discourse of ongoing threat.

A trenchant set of recent interventions take aim at orthodox security studies and left critiques of it. Reorienting the confrontation with (in)security as an analytical and political, anti-capitalist project, the articulation of anti-security studies found in the work of Mark Neocleous and George Rigakos, both separately and together (Neocleous \& Rigakos 2011; Neocleous 2008), confronts the fundamental assumption that security remains good and necessary even in the face of critique (Neocleous 2008, 3-4). This assumption, while deeply flawed, is far from surprising for, as Rigakos notes, "Security is not just hegemonic, it is hegemony. To be against security today is to stand against the entire global economic system. It seems almost unthinkable" (Rigakos 2011, 58). Malleable and ubiquitous as it appears, the concept of security, and its critical counter insecurity, serve as a shield for exploitation and displacement endemic to capitalism. Thus, as Rigakos continues, "[ $\mathrm{t}$ ] he ability for security to latch itself on to most aspects of

\footnotetext{
${ }^{4}$ Here the names of Canadian citizens Abousfian Abdelrazik, Abdullah Almalki, Maher Arar and Ahmad El-Maati (among others) are synonymous with the most egregious effects of the so-called war on terror, including detention, rendition and torture. And we also might point to efforts to 'protect' (Muslim) women from Muslim men evident, for instance, in Canada's official citizenship guide, Discover Canada (2012), which states: "In Canada, men and women are equal under the law. Canada's openness and generosity do not extend to barbaric cultural practices that tolerate spousal abuse, 'honour killings,' female genital mutilation, forced marriage or other gender-based violence" (9).
} 
human relations must... be recognized as an analytic and political blockage" (Rigakos $2011,60)$.

In the context of the political economy of policing and capital, Neocleous and Rigakos deploy the concept of pacification to challenge security's obfuscation, reification and ultimately objectification within contemporary security orthodoxy and the surrounding academic 'cottage industry' of apology and critique. That is to say, 'security' obfuscates resistance to injustice by recasting it as an ongoing threat; it is reified and as such obscures unequal social relations; and it is objectified as a topic that shapes academic disciplines and discourse. Problematizing (in)security's objectives and rejecting "the roundly positive associations now inextricably bound up with the bourgeois concept of security" (Rigakos 2011, 62), pacification instead highlights what Neocleous calls "the fabrication of a social order" (Neoclous, 2000; Rigakos 2011, 62, 64). Because the “population' will never feel secure", police power and capital accumulation are inextricably twinned through a never-ending purpose: rendering the labouring population productive (Neocleous, 2011; Rigakos 2011, 64).

Embedded within an anti-security application of pacification is an interrogation of private property relations and the violence which underwrites it (Rigakos 2011, 64). Yet this violence is met with challenge of varying degrees and kind. Migrant workers self organize and mount resistance through, for instance, shirking, foot dragging and collective withdrawals of their labour power (Smith 2005). Whereas a focus on (in)security portends toward passivity, pacification does not (Rigakos 2011, 64). Resistance, therefore, is a presupposition of the need for pacification, as other essays in this volume also suggest.

Here, I extend the anti-security account of pacification into the policing of migratory status, citizenship and national belonging focusing specifically on temporary labour migration to Canada. In this respect, I attend to the role of Canada's migration regime in the fabrication of productive labour. Constructed on the basis of what Rigakos terms "the global interconnectivity of pacification" $(2011,64)$, that regime is reliant upon a complex transnational regulatory dynamic and requires attentiveness to racialized and gendered class dimensions of pacification globally. It is this latter point which I develop within the context of a discussion of global apartheid.

\section{Identifying Global Apartheid}

A marked level of ambivalence surrounds the explanatory utility of global apartheid. A number of scholars deploy the term without making explicit the empirical and normative bases for doing so (Köhler 1995). The 1973 adoption by the UN General Assembly of the International Convention on the Suppression and Punishment of the Crime of Apartheid established "the crime of apartheid" as a "crime against humanity" 
which, among other things, "violat[es] the principles of international law" and "constitut[es] a serious threat to international peace and security" (Vandewoude 2010). South African apartheid, of course, provided the exemplary instance. In his 1984 Nobel Peace Prize acceptance speech in Oslo Desmond Tutu posited that the crime of apartheid in South Africa rests "on a whole phalanx of draconian laws". Interestingly, while not referring to "global apartheid", Tutu understood South African apartheid as "a microcosm of the world and an example of what is to be found in other lands in differing degree". In obvious reference to the Convention, Tutu spoke of the absence of "peace and security" due to the lack of justice in South Africa - "a land bereft of much justice, and therefore without peace and security" - and tied this to the "global insecurity" of the Cold War era and the threat of "nuclear holocaust".

By the early 2000s the idea of global apartheid garnered considerable salience for reformists within the global ruling elite. Two prominent examples can be found in the words of Juan Somavía (2000), then Director-General of the International Labour Office, and Thabo Mbeki, the presidential successor to Nelson Mandela who, along with Mandela himself, acted as a key architect of neoliberalism on the African continent. In a speech in 2000 reflecting on the unequal composition of labour markets around the globe, Somavía noted how "we can begin to see the shape of a new global apartheid, based on [one's] options for work, for sustainable livelihoods". Within a couple of years, and almost two decades following Tutu's intervention and three since the adoption of the Convention, Mbeki described international political economy as "a global system of apartheid" unsympathetic to nature and human life. ${ }^{5}$

Around the same time and in similar terms, albeit backed by heterodox sensibilities, economist Samir Amin (2001) makes a more pointed use of the concept in linking the logic of neoliberal globalization with "that of organizing apartheid on the global scale", or what he terms "the new apartheid global imperialist system". Amin points to the WTO's development of an "international business law which is given priority over any national legislation", the "scandalous project of a "Multinational Agreement on Investment' prepared in secret by OECD countries", and NATO, as examples of the "project of legalizing apartheid on a global scale". Similarly, political economist Patrick Bond refers to "the Bretton Woods component of global apartheid" (Bond 2004a, 103). From this perspective, global apartheid implicates international and regional institutional structures, especially institutions of trade, finance, militarism and

\footnotetext{
${ }^{5}$ In his August 2002 speech at the Welcoming Ceremony for the World Summit on Sustainable Development (WSSD), Mbeki stated: "We have all converged at the Cradle of Humanity to confront the social behaviour that has pity neither for beautiful nature nor for living human beings. This social behaviour has produced and entrenches a global system of apartheid. The suffering of the billions who are the victims of this system calls for the same response that drew the peoples of the world into the struggle for the defeat of apartheid in this country" (cited in Bond 2004b, 817).
} 
economic integration. These so-called "financiers of global apartheid" (Booker \& Minter 2001) facilitate trans-border flows of capital and capitalists.

The relative salience of these understandings notwithstanding, I adopt a different meaning of the concept of global apartheid. I generally accept its conceptual application to deepening labour market segmentation and intensifying social differentiation of international institutional policies. But there is a need to problematize the perpetuation of security as a greater good and insecurity as a critical tool transcendent of the failings of liberal theory. This perpetuation and fetishization of security masks or obfuscates the dangerously illusionary premises of the idea (Neocleous \& Rigakos 2011, 15). What it misses, therefore, is the opportunity to interrogate apartheid's machinations as pacification. Apartheid is not indicative of insecurity; it is indicative of pacification.

On the account adopted here, the conceptual deployment of global apartheid extends beyond semantics, metaphor or even slur, and for that matter beyond the exceptional treatment of racialization evident in a focus on racial profiling. This account, quite crucially, also reorients attention away from the neo-institutionalism of heterodox global political economy. Whereas Amin, Bond and others emphasize (and perhaps essentialize) global institutional bodies, here I stress the impacts of neoliberal migration on labouring bodies and, consistent with the work of Nandita Sharma and Anthony Richmond, on migrant labouring bodies in particular. The pivotal concern turns on the structuring of temporary labour migration by and through apartheid, understood as a racialized and gendered class phenomenon directed at rendering the labouring population productive.

For Sharma, the "ever-widening differentiation" of global apartheid occurs "through restrictive immigration policies" which "imprison[s] impoverished people within zones of poverty" (2006, 29; also Richmond 1994). Global apartheid's instruments of enforcement are, according to Richmond, "interdiction, passports, visas, residence permits, work permits, denial of citizenship rights, including access to education, government-funded health and welfare services" (Richmond 2002). These of course cover the range of immigration admissions policies but particular consideration has been given to those related to asylum seeking (Richmond 1994), human trafficking and temporary labour migration (Sharma 2005; 2006). In this latter respect, Sharma's incisive intervention has attended to the "oppressive practices" of national border creation and maintenance as understood through the impact of nationalist ideologies and "the exclusionary notion of homelands" $(2006,30)$. The focus here rests more with those instruments and practices specific to Canada's temporary labour migration regulatory regime. 


\section{Canada's Apartheid Migration Regime As Pacification}

Unfree labour is introduced here to operationalize the regulation of migrant labouring bodies. The concept connotes the imposition of political and legal compulsion coupled with, in certain instances, the use of physical force (Miles 1987, 31; Satzewich 1991). Workers characterized as unfree labour provide their labour power by dint of not merely "dull" economic compulsion but also by politico-legal and/or physical compulsion. Shunning the apparent binary distinction between "free" and "unfree", socio-legal historians and theorists have developed more nuanced understandings reflective of an intricate continuum of compulsions (Hay \& Craven 2004).

Despite the economic pressures or compulsion faced by workers, capital accumulation processes cannot satisfy the subsistence needs of all people subject to them. The ever-expanding or globalizing logic of these processes creates "countervailing tendencies" in which we find "a tendency of capital to increase the labour population, as well as constantly to posit a part of it as surplus population" (Marx cited in Satzewich $1991,5)$. The formation of this surplus population, or what Marx called a reserve army of labour, facilitates capital accumulation just as it undermines that same reserve army so that reservists, again to follow Marx, "always stan[d] with one foot in the swamp of pauperism" (cited in Satzewich 1991, 5). Migration, both within national territorial borders and across them, provides something of an alternative to pauperism and to the unevenness of capitalist development, but it, in turn, may also reproduce capital accumulation. In Vic Satzewich's words, "Capital accumulation initially propels or forces certain groups of people to migrate because of the associated economic dislocations which accompany it. Capital accumulation is also the stimulus to migration to the extent that it constitutes the conditions which give rise to labour shortages and points of attraction for wage labour" $(1991,8)$. However, as Satzewich maintains, this is contingent on the distinct forms that migration takes under capitalism, or the modes of incorporation of foreign-born workers, which is structured through state intervention. Of the four such modes deployed in twentieth-century Canada -- free immigrant labour, unfree immigrant labour, free migrant labour and unfree migrant labour - the latter best characterizes Canada's approach to temporary labour migration in the twenty-first century.

Throughout its history as a white settler colonial society, accumulation processes in Canada have relied upon labour migration. Canada's Seasonal Agricultural Worker Program (SAWP), Live-In Caregiver Program and Low-skilled Pilot Project (known formally as the Pilot Project for Hiring Foreign Workers in Occupations that Require Lower Levels of Formal Training), all components of the early twenty-first century Temporary Foreign Worker Program (TFWP) (See Satzewich 1991; Stasiulis \& Bakan 2005; Sharma 2006; Choudry et al. 2009; Fudge \& McPhail 2009), turn on the deployment of unfree migrant labour whereby dull economic compulsion is sharpened through 
politico-legal compulsion. Although the use of migrant workers through the TFWP relies on economic compulsion generally, migratory status is the fundamental politico-legal mechanism of labour unfreedom. The pivotal instrument is the temporary work permit or authorization which subjects non-citizens to the constant threat of repatriation (Sharma 2006; Goldring, Berinstein \& Bernhard 2009. See also Walia 2010). Unfree migrant labour is deployed in Canada on a time-limited basis, anywhere from several weeks to upwards of eight months under the SAWP, or for a maximum of four years under the Low-skilled Project. These migrant workers are tied exclusively to a specific employer within a defined geographic locale. For instance, workers under the SAWP are not permitted to circulate freely in the labour market and must return home at the end of their work authorization or at any other moment determined by employers. These workers experience severely circumscribed labour market and geographic mobility within Canada (Smith 2005). They are permitted to remain in the country only for the duration of their employment arrangement and, on the prerogative of growers, can be forced to leave sooner. During their authorized period of stay, seasonal agricultural workers may not alter the conditions of their authorization, change occupations or take on additional employment without the written approval of a federal immigration official, and a transfer contract approved by a representative of their home government and the prospective employer (Smith 2013).

The essential claim, then, is that Canada's temporary labour migration regime is organized on the politico-legal compulsion of migrant labour unfreedom which functions for the purposes of pacification. Migrant labour is pacified to the extent that it is rendered unfree in practice, through the imposition of state-sanctioned limits on labour market and geographic mobility and on migratory status. Within this regime, the rendering of migrant labour as productive is recurring and transnational. Elsewhere I have attempted to further conceptualize the legal regulation of migrant labour through the dynamic of what Mohapatra (2004) calls "mobilize to immobilize", in order to capture its transnational contours. In other words, TFWP workers are mobilized to cross territorial borders only to be immobilized within Canada. Most notably, the SAWP workers who make the annual trek to Canadian fields and greenhouses to harvest crops are governed by the regulatory dynamics of mobilization and immobilization which frame the specific relations and conditions of unfreedom in which they find themselves. In this respect, the regulatory outcome is not the construction of "desirable future citizens", to employ Prime Minister Mackenzie King's words (cited in Walia 2010 at 7980). Nor is the focus on simply jettisoning "undesirables" (See Pratt 2005). Rather transnational regulation of temporary labour migration produces and reproduces productive labour which is racialized, unfree and migrant. ${ }^{6}$ Because this occurs on a

\footnotetext{
${ }^{6}$ An area in need of sustained inquiry relates to transnational legal relations. The role of law as one of the definitive forces that shape the experiences of migrant workers typically is focused on 'destination
} 
recurring basis through restrictive instruments of apartheid, especially the temporary work permit, the outcome shifts between the construction of racialized unfree migrant labour as 'desirable undesirables' during moments of mobilization and 'undesirable desirables' during immobilization. In both instances, to reference a long-standing slogan, workers so categorized are deemed good enough to engage in paid work in Canada, but not to stay.

The temporary labour migration regime accords with the historically selective nature of the Canadian nation-building project. Working to deepen hegemonic whiteness, the TFWP is a project of pacification designed to produce and reproduce social conditions in which labour is rendered productive on devaluing and inferiorizing terms. As a project of pacification, the TFWP becomes the way in which capital and states attempt to mediate their fundamental reliance on the surplus value of labour. It forms a sort of "spatial vent", release or fix against "the problems of accumulation and legitimation" (Samers 1999, 188 and generally) within Canada and within sending states, and against not only the intensely exclusionary urges of the polity in Canada but also the aspirations and objections of migrant workers themselves. But this approach merely displaces or forestalls concerns - it cannot do away with them forever. The particularized construction and devaluation of migrant labouring bodies on the terms discussed herein re-produces global apartheid. Yet these remain contested terms. In anticipation of the threat of resistance of migrant workers (and their allies), and due to actually existing resistance, migrant labour is subjected to the pacifying forces of temporary work permits, repatriation and tenuous migration status to mobilize yet immobilize these workers.

\section{The Canadian State and Pacification}

A key contradiction of temporary labour migration stems from the growing need for "armies of offshore labour" within Canada and on a global scale. The 'structural necessity' claim (see Thomas 2010) presents an especially acute challenge for capital and the Canadian national state. ${ }^{7}$ Despite certain mainstream perceptions that it is freed from

countries'. Conceptions of legal regulation bounded by the nation-state constrain understandings of the regulatory dynamics of certain labour migration regimes. A transnational articulation need not undermine sustained analysis of the role of national states, and especially the Canadian state, in the regulation of labour migration. Indeed, it is precisely the need to account for the imperialist commitments of the Canadian state, coupled with the neoliberal developmentalist commitments of the sending states, which calls for a trenchant, anti-imperialist framework of analysis. I do not mean to downplay the "heavy lifting" performed through sending state apparatuses. Rather, I aim to accept that, because the SAWP rests upon the hierarchies of the national state system and uneven capitalist development, as discussed below, the imperialist project of the Canadian state ultimately structures relations within the SAWP. From this perspective, any serious analysis must hold the role of the Canadian state to account.

${ }^{7}$ The claim is wanting for sustained interrogation, but I cannot do it justice in the present analysis. There is a need to interrogate it on a number of bases including through an interrogation of capital's incessant need 
national state constraints owing to the hyper-competitiveness of contemporary migration on a global scale, capital remains deeply beholden to the politico-legal interventions of states, sending and receiving. In this way, the nation-state system orchestrates these moves, thereby constructing what amounts to a "global interconnectivity of pacification". What is evident, therefore, is that this interconnectivity is set within the hierarchical and uneven logic of national states and global capital accumulation. To the extent that the contemporary Canadian state wields imperial or sub-imperial power, and there is ample evidence to this end (see e.g. Gordon 2010), especially within the key migrant-sending region of Latin America and the Caribbean, but also more widely through the WTO and other international institutions (and, in this respect, we might reintroduce the neoinstitutional intervention of heterodox global political economy), inequalities between national states are brought to bear on labour migration.

Yet the ultimate focus of an anti-security account of migration regulation must rest not on institutional bodies but on labouring ones. After all, it is the efforts and exertions of labouring bodies that provides the most significant source of wealth within global capital accumulation; and it is from these bodies that resistance emanates. An anti-security intervention attentive to pacification captures the active and ongoing processes in which labouring populations are rendered productive. The challenge to antisecurity is to perceive global apartheid as systemic outcome and integral feature of labour's productive rendering. There remains a longstanding need within leftist theory and practice in Canada, including within Marxist praxis, to take seriously the racialized and gendered, class dynamics of global capitalist order. Although not merely reducible to it, apartheid is not distinct from capitalist development either. It is not a historical accident that exploitation and displacement so crucial to capitalist relations takes on racialized and gendered proportions within territorial borders and across them. It is out of the deeply troubling constructions of labour as productive - in racialized, unfree and migrant forms - that the perception of outsider 'security' threat flourishes. But how then can some claim that migrant labour is a structural necessity within contemporary capitalism in Canada? How do these seemingly contradictory claims co-exist together? Their co-existence, I contend, owes a great deal to the work that migrant labour regulation performs in normalizing and enforcing the apartheid conditions of global capitalism. The continuing construction of racialized and gendered class relations within and between national states serves to bolster capital accumulation. Thus global apartheid appears as one face of the transnational pacification of racialized working class people. Those interested in pacification, as an alternative to 'security' studies, ought to turn their attention to this crucial dynamic of contemporary global capitalism.

for labour and the socio-cultural construction of 'skill', only the former of which I concern myself with here. 


\section{Conclusion}

In the contemporary context of migration management, Canada's temporary labour migration regime forms a project of pacification that enforces global apartheid. The 'structural necessity' of migrant labour in Canada presents the especially acute challenge for capital and national states to render labour productive. This makes capital deeply beholden to the interventions of sending and receiving states. These states intervene by imposing conditions and relations of unfreedom through transnational migrant labour regulation. Canada's apartheid migratory regime is situated within the hierarchical and uneven logic of national states and global capitalist order. Pacification is the way in which this regime mediates capital's contradictory yet continuing reliance on unfree migrant labour -- and worker resistance. Through the regulatory dynamics of mobilization and immobilization, 'foreign' subjects are classified and then rendered racialized, unfree and migrant, productive labouring bodies. It is on this basis that migrant labour also is perceived as a menace or 'security' threat to the composition of local communities.

To say that Canada's labour migration regime pacifies is not to ignore the role of worker resistance and political struggles. Indeed, the idea of pacification necessarily accounts for it. As a project of pacification, the regime aims to create the conditions in which resistance is quelled to render labour productive or pacified. This amounts to a reading or accounting of resistance as a defining feature of historical developments for ordinary people. In this respect, the existence of pacification marks an anticipation of resistance, not a denial of it. The anti-imperialist, anti-security challenge is to strengthen and consolidate actually existing resistance to force a rupture in global apartheid, and in the contradictory logic of global capitalism. Status on arrival, unrestricted labour market and geographic mobility, collective organization with a robust right to strike, and extended family reunification, all serve as pivotal oppositional demands on which migrant workers and their allies might push the limits of the prevailing order. But this calls for a deep and broad-based solidarity of migrant and non-migrant workers within Canada and across borders. Solidarity of this kind cannot be constructed without meaningful engagement with the racialized and gendered nature of class articulations in Canada and elsewhere. It cannot be conducted within the outmoded confines of industrial unionism and its insular focus on nationally-bounded labour laws. Nor can it be found within social democratic politics which imprison Canadian left thinking and action in the neoliberal moment, demanding, at most, only modest improvements to welfare within a national context - demands directed only at citizens. The anti-capitalist, anti-imperialist task demands an overt and sustained, oppositional politics in which capital and the supporting national states, beginning with the imperialist Canadian state, are confronted for their ongoing crimes against humanity. 


\section{References}

Aiken, Sherry. 2001. 'Of Gods and Monsters: National Security and Canadian Refugee Policy', Revue Québécoise de Droit International 14, no 2: 1.

Amin, Samir. 2004. 'Globalism or Apartheid on a Global Scale', in Immanuel Wallerstein ed., The Modern World-System in the Longue Durée: 5-30. Boulder, CO: Paradigm Publishers.

Avery, Donald. 1983/1979. 'Dangerous Foreigners': European Immigrant Workers and Labour Radicalism in Canada, 1896-1932. Toronto: McClelland \& Stewart.

Bahdi, Reem. 2003. 'No Exit: Racial Profiling and Canada's War Against Terrorism', Osgoode Hall Law Journal 41, no 2/3: 293-316.

Bakan, Abbie. 2008. 'Reconsidering the Underground Railroad: Slavery and Racialization in the Making of the Canadian State', Socialist Studies 4, no 1: 3-29.

Bannerji, Himani. 2000. The Dark Side of the Nation: Essays on Multiculturalism, Nationalism and Gender. Toronto: Canadian Scholars' Press.

Bond, Patrick. 2004a. 'Should the World Bank and IMF be "Fixed" or "Nixed"?', Capitalism Nature Socialism 15, no 2: 85-105.

Bond, Patrick. 2004b. 'South Africa Tackles Global Apartheid: Is the Reform Strategy Working?', The South Atlantic Quarterly 103, no 4: 817-839.

Booker, Salih, \& William Minter. 2001. 'Global Apartheid', The Nation (July 9): 11-17.

Choudhry, Sujit. 2001. 'Protecting Equality In The Face of Terror: Ethnic and Racial Profiling and s. 15 of the Charter' in Ronald J. Daniels, Patrick Macklem, \& Kent Roach, eds., The Security of Freedom: Essays on Canada's Anti-Terrorism Bill: 367-382. Toronto: University of Toronto Press.

Choudry, Aziz, et al. 2009. Fight Back: Workplace Justice for Immigrants. Halifax: Fernwood.

Citizenship and Immigration Canada. 2012. Discover Canada: The Rights and Responsibilities of Citizenship, online: http://www.cic.gc.ca 
Dauvergne, Catherine. 2005. Humanitarianism, Identity and Nation: Migration Laws of Australia and Canada. Vancouver: UBC Press.

Dauvergne, Catherine. 2009. Making People Illegal: What Globalization Means for Migration and Law. Cambridge: Cambridge University Press.

Dauvergne, Catherine. 2007. 'Security and Migration Law in the Less Brave New World', Social and Legal Studies 16, no 3: 533-549.

Fudge, Judy, \& Fiona McPhail. 2009. 'The Temporary Foreign Worker Program in Canada: Low-skilled Workers as an Extreme Form of Flexible Labour', Comparative Labour Law and Policy Journal 31, no 5.

Galabuzi, Grace-Edward. 2006. Canada's Economic Apartheid: The Social Exclusion of Racialized Groups in the New Century. Toronto: Canadian Scholars's Press.

Goldring, Luin, Carolina Berinstein, \& Judith Bernhard. 2009. 'Institutionalizing Precarious Migratory Status In Canada', Citizenship Studies 13, no 3: 239-265.

Gordon, Todd. 2010. Imperialist Canada. Winnipeg: Arbeiter Ring.

Gordon, Todd. 2007. 'Towards An Anti-Racist Marxist State Theory: A Canadian Case Study', Capital \& Class 37, no 1: 1-29.

Hay, Douglas, \& Paul Craven. 2004. 'Introduction', in Hay \& Craven eds., Masters, Servants, and Magistrates in Britain and the Empire, 1562-1955: 1-58. Chapel Hill \& London: University of North Carolina.

Köhler, Gernot. 1995. 'The Three Meanings of Global Apartheid: Empirical, Normative, Existential', Alternatives: Global, Local, Political 20, no 3: 403-413.

Macklin, Audrey. 2001. 'Borderline Security', in Ronald J. Daniels, Patrick Macklem, \& Kent Roach, eds., The Security of Freedom: Essays on Canada's Anti-Terrorism Bill: 383-404. Toronto: University of Toronto.

Miles, Robert. 1987. Capitalism and Unfree Labour: Anomaly or Necessity?. London \& New York: Tavistock. 
Mohapatra, Prabhu P.. 2004. 'Assam and the West Indies, 1860-1920: Immobilizing Plantation Labour', in Doug Hay \& Paul Craven eds., Masters, Servants, and Magistrates in Britain and the Empire, 1562-1955: 455-480. Chapel Hill \& London: University of North Carolina.

Neocleous, Mark. 2000. The Fabrication of Social Order: A Critical Theory of Police Power. London: Pluto.

Neocleous, Mark. 2011. 'Security as Pacification', in Mark Neoceleous, and George Rigakos, eds., Anti-Security. Ottawa: Red Quill Books.

Ontario (Attorney General) v. Fraser, 2011 SCC 20, [2011] 2 S.C.R. 3.

Pratt, Anna. 2005. Securing Borders: Detention and Deportation in Canada. Vancouver, University of British Columbia Press.

Richmond, Anthony. 1994. Global Apartheid: Refugees, Racism and the New World Order. Toronto: Oxford University Press.

Richmond, Anthony. 2002. 'Social Exclusion: Belonging and Not Belonging in the World System', Refuge 21, no 1: 40-48.

Rigakos, George. 2011. “To extend the scope of productive labour": Pacification as a Police Project', in Mark Neoceleous, and George Rigakos eds., Anti-Security. Ottawa: Red Quill Books.

Samers, Michael. 1999. “"Globalization”, the Geopolitical Economy of Migrant and the "Spatial Vent", Review of International Political Economy 6, no 2: 166-1999.

Satzewich, Vic. 1991. Racism and the Incorporation of Foreign Labour: Farm Labour Migration to Canada since 1945. London: Routledge.

Sharma, Nandita. 2005. 'Anti-Trafficking Rhetoric and the Making of a Global Apartheid', NWSA Journal 17, no 3: 88-111.

Sharma, Nandita. 2006. Home Economics: Nationalism and the Making of 'Migrant Workers' in Canada. Toronto: University of Toronto.

Smith, Adrian A. 2013. 'Bunkhouse Rules: Housing Unfree Migrant Labour In Ontario', unpublished. 
Smith, Adrian A.. 2005. 'Legal Consciousness and Resistance in Caribbean Seasonal Agricultural Workers', Canadian Journal of Law and Society 20, no 2: 95-122.

Somavía, Juan. 2000. 'Remarks by Director-General of the International Labour Office at the Millennium Non-Governmental Organization Assembly', New York, online: $<$ http://www.ilo.org/public/english/bureau/dgo/speeches/somavia/2000/nymay.ht $\underline{\mathrm{m}}>$.

Stasiulis, Daiva K., \& Abigail Bakan. 2005. Negotiating Citizenship: Migrant Women in Canada and the Global System. Toronto: University of Toronto.

Thobani, Sunera. 2007. Exalted Subjects: Studies in the Making of Race and Nation in Canada. Toronto: University of Toronto Press.

Thomas, Mark. 2010. 'Labour Migration and Temporary Work: Canada's ForeignWorker Programs in the "New Economy"', in Norene Pupo, and Mark P. Thomas ed., Interrogating the New Economy: Restructuring Work in the 21st Century: 149-172. Toronto: University of Toronto.

Tutu, Desmond. 1984. 'Nobel Peace Prize Acceptance Speech' (December), online: $<$ http://www.sahistory.org.za/speeches-and-public-statements/desmond-tutusnobel-peace-prize-acceptance-speech-december-1984-oslo->.

Vandewoude, Cécile. 2010. 'The Rise of Self-Determination Versus the Rise of Democracy', Goettingen Journal of International Law 2, no 3: 981-996.

Vosko, Leah. 2006. 'Precarious Employment: Towards an Improved Understanding of Labour Market Insecurity', in Vosko ed., Precarious Employment: Understanding Labour Market Insecurity in Canada: 3-42. Montreal: McGill-Queen's University Press.

Walia, Harsha. 2010. 'Transient Servitude: Migrant Labour in Canada and the Apartheid of Citizenship', Race \& Class 52, no 1: 71-84. 